Christian M. Billing

\title{
Review of Jan Švankmajer: Dimensions of Dialogue Between Film and Art
}

František DRYJE and Bertrand SCHMITT, with Ivo PURŠ. Jan Švankmajer: Dimensions

of Dialogue Between Film and Art. Praha: Arbor vitae, 2013. 508pp. ISBN 978-80-7467-016-9.*

This volume is a welcome addition to the bibliography on Jan Švankmajer from a trio of authors who are experts in their field. The collection aims to fill a gap in scholarship by providing a broadly chronologically structured critical biography, together with several essays that scrutinise hitherto under-examined elements of the artist's work; these aims are amply fulfilled - the volume is a well-researched, well-written and extremely pleasingly designed publication. Structurally the book can be broken down as follows: (i) five interesting and originally focused essays on precise aspects of Švankmajer's work; (ii) a detailed biography of Švankmajer, with critical and analytical commentary (this major part of the book is helpfully broken into three chronological sections and interspersed amongst the chapters); (iii) a well-chosen but brief anthology of Švankmajer's own writings; and (iv) a list of exhibitions in relation to Švankmajer's art and of his theatre and film work. There is also (v) a useful bibliography (which is equally helpfully broken down into: works by Švankmajer, illustrated books about his works, academic monographs about him as an artist and filmmaker, and a selection of shorter articles and chapter-length studies of the auteur's work). The volume is beautifully illustrated throughout, with many colour plates depicting stills from the films and original two-dimensional and threedimensional artworks by Švankmajer - as well as a number of historical documents (such as photographs of the artist in his various historical milieux, and other personal and social ephemera). The volume is principally written by Schmitt and Dryje, with the additional contribution of one chapter: 'Kunstkamera as Švankmajer's Microcosm, which is written by Purš.

Throughout, the volume is highly successful; the theoretical stances adopted by the authors represent intelligent approaches to the artist's work and vary in their intent from precise studies of individual productions and/or moments in Švankmajer's career written large (such as Chapter 1:'Return to Origins - The Setting of The Stag King' (about Švankmajer's graduation project and its influence on his later work); or Chapter 2: 'Jan Švankmajer and Johannes Doktor Faust by Emil Radok - From Primitive Myth to the Crisis of Civilisation'). Other chapters provide consideration of Švankmajer's developing oeuvre by means of full analysis of defined periods of time (such as Chapter

\footnotetext{
* Also published in Czech as: Jan Švankmajer: Možnosti dialogu: mezi filmem a volnou tvorbou. Praha: Arbor vitae, 2012. 508pp. ISBN 978-80-7467-015-2.
} 
4: 'The Artworks of 1958-1968). In such an 'epochs' or 'sections of time' vein also fall the highly illuminating three sections of the 'Detailed Biography with Commentary', which are all chronologically orientated, and broken into periods of 36,18 and 22 years respectively. These inter-chapter narratives (they are placed between the more theoretically inclined sections of the book) map onto phases of Švankmajer's life and works; but they also correlate quite obviously to significant periods of Czech social and cultural history (i.e. pre-WWII (a short section covering Švankmajer's childhood) to the period of so-called 'Normalisation'; the years of so-called 'Normalisation' to the Velvet Revolution; and the post-Velvet Revolution period). Lastly, there are two more wide-angle theoretical studies, which attempt either to place Švankmajer within an artistic genre, such as Surrealism (in this approach Chapter 7: 'Jan Švankmajer, Surrealist') or to undertake analysis of a characteristic technique or attribute of the auteur's work (such as Chapter 6, the abovementioned: 'Kunstkamera' as Švankmajer's Microcosm').

To assess each aspect of the volume, then, according to its merits: Chapter 1, on Švankmajer's graduation project of 1958, Carlo Gozzis The Stag King, is a fantastic exercise in historiographical analysis. The form and content of Švankmajer's radical reinterpretation of his sources in this early work is used as a touchstone to reflect upon his later works, including major films like Don Juan, Faust, Little Otik and Lunacy and an analysis of how Švankmajer's development of metaphor, surrealist manip- ulation of alienatingly juxtaposed familiar objects and his obsession over certain themes (such as marionettes as an indicator of sovereignty) are well considered in a fluent and convincing analysis of the significance of this formative period and earliest major work. Chapter 2 deals with Švankmajer's input into a medium-length film by Emil Radok (the younger brother of the renowned theatre director Alfréd), which was itself based on a Central European puppet play variant of the Faustus myth. Schmitt makes much of the rootedness of the puppet tradition and the Faust legend in Prague and therefore his opening sections segue well into the significance of the puppet manipulation role that Švankmajer took in this film. Throughout the chapter, Schmidt analyses the film from the perspective of theatricality, the developing aesthetic of stop-frame animation of archaic-looking two dimensional images ('olden-day books'), of live action, puppet manipulation, extreme close- -ups, dissolves and other techniques that were later to be come Švankmajer's stock in trade. Again the analysis is first-rate and informative.

Turning the page, one sees a cute little sepia photograph of Švankmajer as a baby - and the first section of the biography begins as Chapter 4. This section, for obvious reasons, only begins to get going in the 1950s; but it is a joy to read. It is (like all of the biographical interventions) crammed with useful insights into the artist's development and is intelligently illustrated with works from the relevant years that speak to the narrative of the section's pages. Both the photographs and 
the narrative text capture wonderfully the explosive, anarchic, hopeful spirit of the 1960 s - and theatre and film work is set against sculptural and other artistic works in ways that illuminate the subjects well.

Chapter 4 is a brilliantly defined study of artworks: graphic pieces, watercolours, pen-and-ink sketches, mixed-media collages and objects; here both Švankmajer's techniques (set in art-historical contexts) and the abstract or Surrealist impact of the works is well accounted for. A particular strength of the chapter is the way in which Schmidt articulates Švankmajer's quest for the 'soul' of objects, his knack of finding ways for the material to signify something of an inner depth that allows the work to connect with and communicate to the human spirit, in both intellectual and visceral ways. Chapter 5 - a continuation of the biography, dealing with the period of Normalisation to the Velvet Revolution - is masterful. The section is of immense interest for its detailed account of the successes, frustrations and creative problems of such a politically difficult but artistically charged period. With revelations about secret samizdat volumes of Surrealist poetry, to detailed analysis of his widely acclaimed film Alice the section is a masterclass in documentary presentation.

Chapter 6 is the sole contribution to the volume by Ivo Purš, but it does not disappoint. Taking as its framing device the notion of the Kunstkammer (the Renaissance and Baroque 'room of wonders', as popularised in the art of Rudolfine and Mannerist Prague) - Purš analyses Švankmajer's departure from that visually complex but intellectually simple form to create instead a new realm of art in which '[a]lthough the artist draws from a variety of sources, his creative synthesis is not eclecticism nor does it reveal a priori concepts' but rather it 'exists as pure self-fulfilment through creativity, in which the artist is part of his work, and the work stands as a completion, one that is constantly evolving, of his personality'. Purš thesis is persuasive and is used to argue for an understanding of all of Švankmajer's art: film, graphic, painterly, sculptural... as an extension of one man's imagination and a way of conceptualising a world [but maybe not the world] around him, drawn from the peculiarities of his own imagination. Thus we have explained for us in a new and exciting way Švankmajer's Arcimboldo-inspired portraits and sculptures and his pastiches and parodies of nineteenth- and early-twentieth century anatomies and worlds of natural history as exercises in mind-mapping and Surrealist fantasy, pushing at the boundaries of perception and the limits of philosophy. Such a chapter bridges well into Chapter 7, by František Dryje, on 'Švankmajer as a Surrealist'. The essay is the longest in the book (104 pages) and bridges the gap from Mannerism to Surrealism, with very good detail on the relevant art-historical and philosophical contexts of both forms and, working with many similar objects to the previous chapter, providing new critical insights and interpretations that add to the depth of analysis (and breadth) that is achieved throughout the volume. Starting with graphic works, moving to sculpture and then progressing to film, before returning once again to sculpture 
and printmaking in 'tactile poems' and cartographic fantasies, Dryje provides commentary on the works that ranges from psychological investigation, through deconstructions of alchemical symbolism, to analysis of the fetish object and the way that art can speak to the nature of human desire. The text is always interesting and it is written with flair; at times, it achieves brilliance.

Chapter 8 provides the concluding section of the biography, with analysis of works in Švankmajer's later years. Here we see the artist at the height of his powers. Editorial work, as well as his artefactual outputs are considered and there is continuing juxtaposition of outputs across all genres (and in ways that speak to each other in interesting respects, such as the following page illustrations of the marionette used for the film Little Otik and an 'African Marionette' art object on the subsequent leaf.

Lastly comes an anthology of Švankmajer's own works, encompassing short essays, sections from manifestos, poems, dream recollections, statements on concepts (such as 'fetish'), explications of films, extracts from screenplays, and other brief but insightful pieces of written engagement, and a full and detailed bibliography.

The authors of this volume, their editors, the publishing house and its layout artists are to be congratulated. In formulating and accomplishing this book they have done justice to their polymath subject - and THAT is quite some compliment! 